\title{
Physical Activity for the Prevention of Cardiometabolic Diseases: how much is Required?
}

\author{
Francisco José Gondim Pitanga ${ }^{1 *}$, Cristiano Penas Seara Pitanga ${ }^{2}$ and Carmem Cristina Beck ${ }^{3}$ \\ ${ }^{1}$ Universidade Federal da Bahia, Brasil
}

${ }^{2}$ Integrated Institute of Health (SPORTCLIN), Salvador, Bahia, Brazil

${ }^{3}$ Instituto Federal da Santa Catarina (IFSC), Brazil

Submission: January 10, 2019; Published: January 25, 2019

*Corresponding author: Francisco José Gondim Pitanga, Universidade Federal da Bahia, Av. Miguel Calmon, s/n - Vale do Canela - Salvador, Bahia, Brasil

\begin{abstract}
The interest of the researchers in investigating the amount of physical activity best suited to provide health benefits is not recent, but the type and amount (duration and intensity) of physical activity more adequate to protect health problems still needs to be better studied The purpose of this point of view is to suggest the type and quantity (duration and intensity) of physical activity most adequate for the prevention of cardiometabolic disorders in adults. The evidences that will be presented are part of publications about the type and quantity (duration and intensity) of physical activity necessary or sufficient for the prevention of cardiometabolic disorders produced by a group of Brazilian researchers, as well as longitudinal publications on the dose-response effect of the physical activity for mortality prevention found in the international literature. Considering the accumulation of evidence presented in the literature consulted and also based on the studies on the amount of physical activity necessary to prevent hypertension, diabetes and cardiovascular events published by the group of researchers linked to different institutions of higher education in Brazil the type and amount (duration and intensity) of physical activity most adequate to provide cardiometabolic benefits is: leisure time physical activity in moderate / vigorous intensity lasting 180 to 300 minutes per week for men. For women, is recommended leisure time physical activity in moderate to vigorous intensity or walking lasting 150 to 300 minutes per week. Therefore, it is suggested that this information be widely disseminated so that the benefits of physical activity as a means of promoting health can be maximized.
\end{abstract}

Keywords: Physical Activity; Prevention; Cardiometabolic Diseases; Diabetes; Cardiovascular; Hypertension; Duration; Intensity; Health benefits; Sports medicine; Control and Prevention; Aerobic activity

Abbreviations: CDC: Centers for Disease Control and Prevention; ACSM: American College of Sports Medicine; WHO: The World Health Organization; NCDs: Non-Communicable Chronic Diseases; ROC: Receiver Operating Characteristic

\section{Introduction}

The interest of investigators to investigate the amount of physical activity best suited to provide health benefits is not recent. In 1992, a group of scholars [1] sought answers to the dose of physical activity more appropriate to provide more significant effects to protect several health problems. At that time, it was suggested that adult individuals should accumulate at least 30 minutes of walking per day for health benefits. Subsequently, in 1995, two institutions of renowned international competence, the Centers for Disease Control and Prevention (CDC) [2] and the American College of Sports Medicine (ACSM) [2] have recommended that in order to gain protection for cardiovascular and metabolic disorders, adults should accumulate thirty minutes of moderate intensity physical activity on most days of the week.
The World Health Organization (WHO) in 2010 suggested to adults (18-64 years) 150 minutes of moderate aerobic physical activity or 75 minutes of vigorous aerobic physical activity per week or an equivalent combination of moderate and vigorous physical activity for prevention of cardiometabolic disorders. To beneficiaries the additional health, recommended an increase to 300 minutes of moderate aerobic physical activity or 150 minutes of vigorous aerobic physical activity, or an equivalent combination of moderate and vigorous physical activity and physical activity vigorous strengthening exercises involving large muscle groups two days or more per week. Also emphasize the importance of regularity activities adhesion strengthening of large muscle groups suggesting that these activities are combined aerobic activity two or more times a week [3]. 


\section{Current Research in Diabetes \& Obesity Journal}

Although it is well documented in the literature that regular physical activity decreases the risk of developing noncommunicable chronic diseases (NCDs), coronary diseases, type II diabetes and some forms of cancer 3 , the type and quantity (duration and intensity) of physical activity more adequate to protect health problems still needs to be better studied. In this way the main objective of this point of view is to suggest the type and quantity (duration and intensity) of physical activity more adequate for prevention of cardiometabolic disorders in adults.

\section{Scientific Evidence Produced by Brazilian Research Group}

Evidence presented this point of view are part of publications on the type and amount (duration and intensity) of necessary or sufficient physical activity to prevention of cardiometabolic disorders produced by group of Brazilian researchers and longitudinal studies on the dose-response effect of physical activity for mortality prevention found in the international literature and linked to the studies presented in Table 1.

Table 1: Studies with publications on the type and amount (duration and intensity) of physical activity necessary or sufficient to prevent cardiometabolic disorders in adults.

\begin{tabular}{|c|c|c|c|}
\hline Study & Objective & Sample & Local \\
\hline $\begin{array}{l}\text { Obesity reverse } \\
\text { epidemiology }\end{array}$ & $\begin{array}{l}\text { Identify the factors associated with } \\
\text { cardiovascular comorbidities in obese women } \\
\text { with normal blood pressure, glycemia and } \\
\text { plasma lipids }\end{array}$ & $\begin{array}{l}387 \text { obese women with aged } \\
\text { between } 21 \text { to } 75 \text { years }\end{array}$ & Salvador-Bahia, Brazil \\
\hline $\begin{array}{l}\text { Prevalence, causes } \\
\text { and consequences of } \\
\text { physical activity. }\end{array}$ & $\begin{array}{l}\text { To identify the prevalence, causes and } \\
\text { consequences of physical activity in the } \\
\text { municipality of Lauro de Freitas, Bahia, Brazil }\end{array}$ & $\begin{array}{l}522 \text { adults, } 220 \text { males and } 302 \\
\text { females older than } 18 \text { years. }\end{array}$ & Lauro de Freitas-Bahia-Brazil. \\
\hline $\begin{array}{l}\text { Study on the } \\
\text { health situation of } \\
\text { the ethnic black } \\
\text { population }\end{array}$ & $\begin{array}{l}\text { To identify the health situation in adults of the } \\
\text { ethnic black population in the city of Salvador- } \\
\text { Bahia }\end{array}$ & $\begin{array}{c}2.305 \text { black adults aged between } \\
20 \text { and } 96 \text { years, } 902(39.1 \%) \text { of } \\
\text { whom were men }\end{array}$ & Salvador-Bahia , Brazil \\
\hline $\begin{array}{l}\text { Longitudinal Study } \\
\text { of Adult Health ( } \\
\text { ELSA-Brazil ) }\end{array}$ & $\begin{array}{l}\text { Investigate theincidence and progression of } \\
\text { diabetes and cardiovascular diseases and } \\
\text { their determinants (biological, environmental, } \\
\text { psychological and social factors) }\end{array}$ & $\begin{array}{l}15.105 \text { adults of both sexes, public } \\
\text { servants of six institutions of } \\
\text { education and / or research with } \\
\text { age, in the baseline, between } 35 \\
\text { and } 74 \text { years }\end{array}$ & $\begin{array}{c}\text { Salvador, Bahia; Rio de Janeiro, } \\
\text { Rio de Janeiro; São Paulo, São } \\
\text { Paulo; Vitoria, Espírito Santo; } \\
\text { Belo Horizonte, Minas Gerais; } \\
\text { Porto Alegre, Rio Grande do Sul } \\
\text {, Brazil }\end{array}$ \\
\hline $\begin{array}{l}\text { The Sax Institute's } \\
45 \text { and Up study }\end{array}$ & $\begin{array}{l}\text { Conduct research that contributes to policy } \\
\text { decisions, programs and health service delivery }\end{array}$ & $\begin{array}{l}267.153 \text { adults of both sexes over } \\
45 \text { years of age }\end{array}$ & New South Wales, Austrália. \\
\hline $\begin{array}{l}\text { National Health } \\
\text { and Nutrition } \\
\text { Examination Survey. }\end{array}$ & $\begin{array}{l}\text { Assess the health and nutritional status of } \\
\text { adults and children }\end{array}$ & $\begin{array}{l}16.049 \text { adults of both sexes with } \\
\text { aged between } 18 \text { and } 85 \text { years }\end{array}$ & United States of America. \\
\hline
\end{tabular}

One of the first works produced by research was published in 2010 with data from the study "Prevalence, Causes and Consequence of Physical Activity ". The objective was to assess the intensity of physical activity (walking, moderate and vigorous) in different domains (work, commuting, domestic activity and leisure time) as predictors of the absence of diabetes [4]. Receiver Operating Characteristic (ROC) curves were constructed and computed to the areas between the intensities of physical activity in the various domains and the absence of diabetes. The main results showed that the walk alone was not a good predictor of the absence of diabetes. It was also observed that accumulate physical activity in different domains by 185 minutes/week at moderate intensity, or even made by 285 minutes/week walk intensity, moderate or vigorous were the best cutoff points for predicting the absence of diabetes.

In sequence at publication with data from the "Study on the health situation of the ethnic black population " in order to analyze the quantity (intensity and duration) to total physical activity and its different domains (work, commuting, domestic activity and leisure time) as predictors of absence of diabetes in a population of $\mathrm{n}$ black ethnicity [5] was observed that among the different amounts of physical activity studied were found to be more statistically significant in the areas under the ROC curve in the physical activity of moderate intensity performed in leisure time and in work among men, and in the commuting among women. The walk alone was not good predictor of the absence of diabetes, this time only among men. It was also observed that 185 minutes week of physical activity accumulated in the different domains for men and 215 minutes/week for women were the best cut-off points to predict the absence of diabetes, but after multivariate analysis, there was an association between physical activity and diabetes only among men.

Subsequently, in another publication with the objective of analyzing the intensity and duration of physical activity sufficient to discriminate the absence of cardiovascular comorbidities in obese women [6], with data from the study "Reverse obesity epidemiology", it was observed that among the different activity intensities the highest areas under the ROC curve were found in the walk: 0.68 (0.62-0.73), with cut-off point for duration of 150 min/week and moderate activity: 0.64 (0.58- 0.70), with cut- 


\section{Current Research in Diabetes \& Obesity Journal}

off point for a duration of $150 \mathrm{~min} /$ week, demonstrating that among obese women, walking alone can be a good predictor of the absence of hypertension, diabetes and dyslipidemia.

Later in the year 2014 in more work even the research group [7], with study data "Prevalence, causes and consequences of physical activity" aiming to analyze the amount (duration and intensity) of physical activity in its different domains (work, commuting, domestic activity and leisure time) as discriminator of the absence of arterial hypertension in males it was shown that among the different domains of physical activity analyzed, there was greater statistical significance in the areas under the ROC curve for physical activity at work and leisure time. Walking was not a good discriminator for the absence of arterial hypertension in any of the domains analyzed. It was also observed that 180 min/week of moderate physical activity accumulated in the different domains was the best cutoff point to discriminate the absence of arterial hypertension.

More recently, two studies involving a group of Australian and American researchers have drawn attention to the amount (duration and intensity) of physical activity as a protective factor for changes in cardiovascular biomarkers also for all causes of mortality. In the first study, conducted in Australia [8], it was observed that among people reporting any physical activity there is an inverse association, with a dose-response gradient, between the proportion of vigorous physical activity and mortality. The authors suggest that vigorous physical activity should be incorporated into the recommendations of physical activity for public health.

In the second study, conducted in the USA [9], the authors concluded that engaging in moderate/vigorous physical activity even below the minimum recommendation was associated with survival benefits, but the greatest effects occurred at a dose of approximately 5 times the minimum recommendation. It is important to emphasize that when are stratified by sex, among women the protective effect for mortality occurs only at the lower intensities, while among men, protection occurs mainly at higher intensities of physical activity.

Finally, in the year 2018, with data from the Longitudinal Study of Adult Health (ELSA-Brazil), an investigation was carried out to verify the association between leisure time physical activity and commuting physical activity with cardiovascular risk scores [10]. The results showed that, although only the practice of leisure time physical activity is inversely associated with cardiovascular events, men need a greater amount (duration and intensity), also with a dose-response effect, than women for the benefits to be achieved.

These results may be partially explained by the fact that in men the resting homeostatic parameters, such as; heart rate, blood pressure, glycemic levels, body temperature, caloric expenditure, among others, are higher than in women. Thus, in order to break the resting homeostasis, they need a greater amount of physical activity (duration and mainly intensity) than women, in order to make the mechanisms that trigger cardiovascular protection, such as reduction of blood pressure, reduction glycemia and triglyceride levels, and the increase in HDL-C (which at rest has lower levels in men than in women) can be activated.

\section{Final Considerations}

Considering the accumulation of evidence presented in the literature consulted and based on studies on the amount of physical activity necessary to prevent hypertension, diabetes and cardiovascular events published by the group of researchers linked to different institutions of higher education in Brazil it is suggested that the recommendations for the practice of physical activity are made based on the Table 2 below. Longitudinal studies on the amount of physical activity required for cardiometabolic benefits in Brazilian adults are also suggested to confirm the evidences observed in the cross-sectional studies analyzed.

Table 2: Recommendations for practicing physical activity in adults of both sexes.

\begin{tabular}{|c|c|c|}
\hline $\begin{array}{c}\text { Physical } \\
\text { Activity }\end{array}$ & Men & Women \\
\hline Type, intensity & $\begin{array}{c}\text { Leisure Time Physical Activity (Sports, Fights, Dances, } \\
\text { Gymnastics, Running, Bike, Bodybuilding, among others) }\end{array}$ & $\begin{array}{c}\text { Leisure Time Physical Activity (Sports, Fights, Dances, } \\
\text { Gymnastics, Walking, Running, Bike, Bodybuilding, among others }\end{array}$ \\
\hline Duration & $180-300$ minutes per week & $150-300$ minutes per week \\
\hline Intensity & Moderate/Vigorous & Walking, Moderate/Vigorous \\
\hline
\end{tabular}

\section{References}

1. Blair SN, Kohl HW, Gordon NF, Paffenbarger RS Jr (1992) How much physical activity is good for health? Annual Review of Public Health 13: 99-126.

2. Pate RR, Pratt M, Blair SN, Haskell WL, Macera CA (1995) Physical Activity and Public Health. A recommendation from the centers for disease control and prevention and the American college of sports medicine. JAMA 273(5): 402-407.

3. (2010) Global recommendations on physical activity for health. World Health Organization, Geneva.
4. Pitanga FJ, Almeida LA, Freitas MM, Pitanga CP, Beck CC (2010) Padrões de atividade fisica em diferentes domínios e ausência de diabetes em adultos. Motricidade 6(1): 5-17.

5. Pitanga FJ, Lessa I, Barbosa PJ, Barbosa SJ, Costa MC, et al. (2010) Physical activity in the prevention of diabetes in black ethnicity: how much is required? Rev Assoc Med Bras (1992) 56(6): 697-704.

6. Pitanga FJG, Lessa I, Pitanga CPS, Costa MC (2011) Atividade física na prevenção de co-morbidades cardiovasculares em mulheres obesas: Quanto é necessário? Rev bras ativ fís Saúde 16(4): 334-338.

7. Pitanga FJ, Beck CC, De Almeida LA, Freitas MM, Pitanga CP (2014) 


\section{Current Research in Diabetes \& Obesity Journal}

Physical activity as discriminator of the absence of hypertension in adult men. Rev Bras Med Esporte 20(6): 456-460.

8. Gebel K, Ding D, Chey T, Stamatakis E, Brown WJ, et al. (2015) Effect of Moderate to Vigorous Physical Activity on All-Cause Mortality in Middle-aged and Older Australians. JAMA Intern Med 175(6): 970-977.

9. Loprinzi PD (2015) Dose-response association of moderate-to-vigorous physical activity with cardiovascular biomarkers and all-cause

his work is licensed under Creative Commons Attribution 4.0 Licens

DOI: 10.19080/CRDOJ.2019.09.555766 mortality: Considerations by individual sports, exercise and recreational physical activities. Prev Med 81: 73-77.

10. Pitanga FJG, Matos SMA, Almeida MDC, Barreto SM, Aquino EML (2018) Leisure-Time Physical Activity, but not Commuting Physical Activity, is Associated with Cardiovascular Risk among ELSA-Brasil Participants. Arq Bras Cardiol 110(1): 36-43.

Your next submission with Juniper Publishers
will reach you the below assets
- Quality Editorial service
- Swift Peer Review
- Reprints availability
- E-prints Service
- Manuscript Podcast for convenient understanding
- Global attainment for your research
- Manuscript accessibility in different formats
( Pdf, E-pub, Full Text, Audio)
- Unceasing customer service
Track the below URL for one-step submission
https://juniperpublishers.com/online-submission.php

